DOI: https://doi.org/10.33989/2075-146x.2021.27.247026

УДК 371.3:81’243(09)

NATALIYA VYKHRUSHCH
ORCID: 0000-0002-8489-7964
Ivan Franko National University of Lviv, Lviv, Ukraine

CONTENT AND METHODS OF TEACHING THE GERMAN LANGUAGE IN SECONDARY SCHOOLS OF WESTERN UKRAINE (SECOND HALF OF XIX EARLY XX CENTURY)

The article deals with the analisys of content and methods of teaching the German language in secondary schools of Western Ukraine in the second half of XIX - early XX century. It summarizes positive historical experience of Western Ukraine in teaching the German language, identifies distinctive features of content and methods of teaching the German language in secondary schools in this period and clarifies the importance of researches by Ukrainian scholars, educators and methodologists in order to improve school educational content in modern conditions. To make teaching of the German language more effective diferent tyres of exercises were used: explanatory reading, reading excerpts from prose and poetic works of the past with oral and written retelling, oral and written translation, copying from a texbook, explanatory dictations, memorizing poems and excerpts from prose and writing them from memory in class, grammar and lexical tests. It has been defined that the ideas about daily study of the German language is well worth noting. Grammatical material cannot underlie the study of the German language and should be used to explain complicated structures in the texts.

Key words: the German language, content, curricula, methods, textbook

Introduction. In the context of reforming secondary schools in Ukraine, content and methods of teaching the German language in secondary schools of Ukraine in the second half of XIX - early XX century seems relevant, since this period is characterized by significant improvement of schooling due to political, economic and cultural changes. The implementation of didactic ideas of the past in the process of the modern school deserves special attention.

Nowadays, despite a large number of researches and significant changes in the theory and practice of teaching foreign languages, there are issues that remain a constant subject of debates. These are the issues of improving existing teaching strategies and search for new ones, a choice of priority teaching methods taking into account pupil's age and stage of development, their individual inclinations, preferred learning styles, specific curriculum demands, time pressure, the use of translation in teaching foreign languages.

Analysis of relevant research. General aspects of teaching the German language in the second half of XIX - early XX century are reflected in the works of prominent scholars, educators and methodologists of the past Chekhovsky (1892), Kokurenych (1896), Pachovsky (1909), Salio (1909), and others.

Some aspects of teaching foreign languages were considered by modern scholars B. Stuparyk, T. Zavhorodnya, I. Kurliak, S. Laba, D. Penishkevych, O. Babina, L. Kobylians'ka, I. Petriuk, V. Styns'ka, S. Chuyko, A. Hembaruk and others.

A comprehensive historical and pedagogical analysis of the theory and practice of foreign language teaching as a component of the content of gymnasium education of Ukraine in the second half of XIX - early XX century was performed by A. Dolapchi.

The aim of the article is to summarize positive historical experience of Western Ukraine in teaching the German language in the second half of XIX - early XX century, identify distinltive features of content and methods of teaching the German language in secondary schools of Ukraine in this period and clarify the importance of researches by Ukrainian scholars, educators and methodologists to improve school educational content in modern conditions.

Results and discussions. The situation with the study of the German language in the Ukrainian lands under the rule of the Austro-Hungarian Empire was much better than that under the rule of the Russian Empire. The teacher Kokurenych (1896) in the pages of the Lviv magazine "Uchytel'" noted that German textbooks, that were published since 1892, were much better because they allowed students to learn the German language, answer questions in the German language, formulate questions in the German language, i.e. to use the German language in spoken and written forms. The German textbook consisted of 40 excerpts, the first 9 of which were printed in Latin and the other 31 in Gothic script. The first three excerpts were based on the rules of sentence structure with the verb "sein" in the present tense, the use of personal pronouns, the declension of the verb "sein" in singular and plural, the use of the predicate, the imperative of the verb "sein" and the structure of interrogative sentences. These were followed by sentences with a personal pronoun, cases of using the objection "nicht", nouns in different genders, questions to the subject and predicate. 
Under the excerpts there was a note that made clear how to use already known and translated phrases or explained the phrase and the rules of its use.

The textbook was based on the following principles:

Teaching the German language on the basis of complete and clear sentences;

Simultaneous expansion of students' grammatical knowledge and the number of learned words;

Uniform division of material for the whole year (Kokurenych, 1896, pp. 245-251).

In textbooks on the German language used by 1892, the first six pages provided a German-Ukrainian dictionary containing several hundred words. The child did not know how to use these words in speech. Interestingly, both before and after 1892, the curriculum stated that the purpose of teaching the German language was to teach young people to use the German language correctly in spoken and written forms. The purpose of teaching the German language was not to teach children German words, rules or examples by heart, but to make them able to use learned expressions and forms, so that the material from the book not only remained in the students' memory, but also helped them to speak the German language with random combination of lexical and grammatical material.

Methodologist Salio (1909) criticized the philological and grammatical method of teaching the German language, which involved translating individual sentences from the German language into the Polish language and vice versa, parallel study of grammar, reading stories from simple ones to complex ones and German classical works. The author considered this method wrong, and argued that teaching a living language must be alive, from the very beginning be based not on translations but on conversations in the German language, at least the shortest ones. He considered grammar a way of learning, not its purpose. L. Salio and his students from the 1st grade used the German language. The language of instruction was used only for the necessary explanations (Salio, 1909, p.98-99).

The first edition of the textbook "German Exercises for the First Grade of Secondary Schools" was published in 1889 by L. German and K. Petelents and consisted of 40 lessons, a German-Ukrainian and Ukrainian-German dictionary, and a grammar part. The lessons had the following topics: family; school; house; garden; city; church; walk; clothing; winter; year, week, month; letter, mail; telegraph; profession; summer; nations and religions; spring; weather; road; forest; watch; day; street; holiday; summer (German, \& Petelenz, 1889).

Each lesson consisted of three short prose excerpts intertwined with poetic ones. The excerpts contained from 7 to 15 sentences and from 40 to 218 words, respectively. Each excerpt was preceded by a reference to a grammatical commentary indicating the paragraph at the end of the textbook that included the following topics: word order in the sentence, declension of nouns, declension of pronouns, declension of adjectives, degree of comparison of adjectives, numeral, declension of verbs, auxiliary verbs, present tense, past imperfect tense, past perfect tense, past tense, future tense, future tense, active and passive voices, prepositions, conjunctions. The names of grammatical categories were given in both languages. These links allowed students to study the grammatical categories contained in the text before reading the excerpts. Each lesson ended with an exercise in translation from the Ukrainian language into the German language, which helped to consolidate the material covered. The translation exercise was structured in such a way that all the sentences could be found in the text if the student had some difficulties.

In the second and third editions, the exercises for translation and the Ukrainian-German dictionary were eliminated (German, \& Petelents, 1898, 1910). In the fourth edition grammar and vocabulary were separated from the textbook, which made it easier for students to work: without turning the pages of the excerpt, they were able to use the grammar chapter and German-Ukrainian dictionary (German, \& Petelenz, 1910).

Chekhovsky (1892) recommended that when teaching the German language in the first grade using the textbook of Herman-Petelenets it was much better to organize words, eliminate unused constructions. He also pointed out that the dictionary lacked many words, some words had to be given another appropriate ending, dictionary sometimes disagreed with the text (Chekhovsky, 1892, pp. 273-276).

"German Exercises for the Second Grade of Secondary Schools" published in 1910 by Hermann and Petelenz contained only lessons consisting of three excerpts. The excerpts contained from 14 to 23 sentences and from 155 to 235 words, respectively. The topics of the lessons were as follows: after the holidays, autumn, paradise, the Trojan War, lighting, proverbs, New Year, river, ocean, laziness and diligence, ship, animals, Gauls in Rome, Hannibal, library, fables, Julius Caesar (German, \& Petelenz, 1910).

The textbook "German Exercises for the Second Grade of Secondary Schools" by Aliskevych and Gamchykevych, consisted of 146 excerpts, 25 of which were poetic. A distinctive feature of this textbook was the division of educational material into months from September to June. This division helped the teacher to present the material on time. 11 pages were occupied by texts for homereading - tales of the Brothers Grimm. At the end of the textbook, a German-Ukrainian dictionary was presented (Aliskevych, \& Gamchykevych, 1914).

"German Exercises for the Third Grade of Secondary Schools" was published in 1901 by Herman and Petelenets and contained 40 lessons, consisting of three excerpts of up to 343 words. The topics of the lessons were the following: school of life, Karl the Great, Rhine, joke, stories, from school life, dedication, legends, man and nature, Constantinople, clocks, fables, Casimir the Great, Columbus, summer (German, \& Petelenz, 1901).

"German Exercises for the Fourth Grade of Secondary Schools" was published in 1892 by Herman and Petelenets and contained 40 lessons, consisting of three excerpts. The topics of the lessons were as follows: order, stories, Charles 
V, Vienna, homeland, air travel, proverbs, Maria Theresa, friendship, W. Dürer. German-Ukrainian and UkrainianGerman dictionaries were provided. There was no grammatical comment. Only a few lessons had translation exercises (German, \& Petelenz, 1892).

In the textbook " Introduction to the German language for the Third Grade of Public Schools" in 1892, first sentences were given in German with translation, then they were slightly modified and more common sentences using words from previous sentences and grammatical notes were provided:
Ich bin jung.
I (am) young
Du bist klein.
You (are) small.
Er ist artig.
He (is) polite.
Sie ist fleißig.
Es ist gesund.
She (is) dilligent.
It (is) healthy.

Ich bin jung und klein. Du bist artig und fleißig. Er ist jung und gesund. Sie ist klein und artig. Es ist gesund und jung. Du bist klein, jung und gesund.

(Introduction to the German language for the third grade of public schools, 1892, p. 1).

Exercises for translation from Ukrainian into German were given to consolidate the material covered. The second part of the textbook contained short texts about the house, school, village, city. At the end, a short German-Ukrainian dictionary of texts was provided.

The following remarks were made to the Petelenz - Werner textbooks for grades 5-8: too high a poetic style and insufficient attention to ordinary, everyday language, too broad and detailed interpretation of the history of the German literature. Concequently, students knew a lot about literature and could not express their everyday thoughts in the German language. The scholar Salio (1909) defended these textbooks and noted that school is not for discussing everyday life and argued that the task of the gymnasium is not to teach a foreign language, the gymnasium should only lay the ground for learning that language. In his opinion, by means of exercises and communication with foreigners, students will begin to use it correctly (Salio, 1909, p.101).

It was correct to think that the teacher could have conversations with students in the German language in the amount of school material and not focus on constant correction of major mistakes (Ippoldt, 1904, p.338).

The textbooks of Ippoldt et Stylo paid more attention to the living, everyday language. It presented several wellknown works of German literature and the most important facts on the history of German literature and culture instead of materials on the historical development of the German literature (Salio, 1909, p.103).

According to Yushchyshyn (1913), Marian Yakymovsky, the author of the "German-Ukrainian Dictionary" and "Introduction to the German Language for the Third Grade of Public Schools", very modestly called his small work: it is not a dictionary, but "a famous nuclear and methodical translation and explanation of all scientific material with special emphasis on German word formation and inflection" (Yushchyshyn, 1913, p. 127). Among the shortcomings, he noted the lack of stresses in German and Ukrainian, expressed a desire to "ukrainianize" some words and phrases.

The new curriculum warned against a detailed explanation of the excerpts read, and instructed to explain them so that it was clear to students of certain age (Pachovsky, 1909, p. 53).

The aim of teaching the German language according to the new curriculum presupposed the following:

Deepening the knowledge of the language, based on the historical explanation of forms when reading ancient works of literature;

Desire to achieve accuracy, fluency in speech and writing and a thorough understanding of the work read;

Knowledge of the historical development of literature from ancient to modern times, knowledge of the main works of literature, based on their own reading (Pachovsky, 1909, p. 54).

The new curriculum indicated that the textbook for the first grade should include poems, tales, legends, fables and short stories that were easy to understand. Poetic excerpts and prose ones were meant for memorization. The number of written works was limited to 6 schoolworks and 3 homeworks in each semester.

In the second grade, excerpts from history, natural sciences, geography, and longer poetic works were added to excerpts-stories. Exercises based on grammatical transformations, first attempts of description were added to the written exercises of the 1 st grade.

The volume of the textbook for the third grade was expanded with larger lyrical poems, descriptions, larger stories, on the basis of which exercises on critical thinking were formed. The textbook provided short biographies of famous writers.

In the fourth grade, the curriculum focused on the features of sentences. Finishing 4th grade the students acquired knowledge about the main types of poetry and prose based on excerpts read in previous classes. The tasks were accompanied by explanations of the meaning of proverbs. Pachovsky (1909) considered it premature and recommended to transfer this task to the 5th grade, and to leave in the 4th grade reports on the read scientific researches which would lay a basis of independent work of this kind (Pachovsky, 1909, p. 55).

In the fifth grade the German language was taught 3 times a week. The subject of study was the history of literature from ancient times to the beginning of the XVI century. The periods connected with original ancient texts were considered in more detail. The textbook should have contained excerpts from the historical development of writing 
arranged in chronological order. In addition to works of writing, the textbook included samples of oral literature. The textbook should have contained excerpts that were not chronologically related, but corresponded to the age and mental maturity of the students, in the form of an appendix taken from the works of new literature (ballads, poetic stories, samples of modern poetry).

Both the lower gymnasium and the higher gymnasium provided conversation exercises, which took place once a week. They had a free topic and were limited to 10 minutes. These were reports about what they had read or about their own lives. There were 5 tasks for the first half of the year (3 schoolworks and 2 homeworks) (Pachovsky, 1909, p. 56).

Conclusions. At the beginning of the twentieth century some progress in the field of methodology of teaching the German language was observed. Discussions on improving teaching the German language intensified in the pages of pedagogical journals. A single methodology was not developed, but some positive results were obtained. In particular, the need to learn the German language was recognized. While teaching ancient languages had a general educational purpose, teaching new languages pursued practical goals. The authors of pedagogical researches were inclined to the idea that it is necessary for students to be able to read the German language, to retell what was read, to be able to compose sentences from the words learned to express their thoughts. The ideas about the daily study of the German language is well worth noting. It has been argued that grammatical material cannot underlie the study of the German language, as it was the case before, but should be used to explain complicated structures in the texts.

Perspectives of the further research. The experience of teaching new foreign languages in secondary schools of Ukraine in the second half of the XIX - early XX century can serve the needs of today and become the subject of further research.

Aliskevych, A., \& Gamchykevych, R. (1914). German exercises for the second grade of secondary schools. Lviv.

Chekhovsky, D. (1892). Attention to textbooks 1) Exercises by German-Petelenets-Kalitovsky, 2) Latin exercises by Samolevich-Soltysik-Tseglinsky, 3) Latin grammar by Samolevich Tseglinsky. Uchytel', 16-17, 273-276.

German, L., \& Petelenz, K. (1889). German exercises for the first grade of secondary schools. Lviv.

German, L., \& Petelenz, K. (1892). German exercises for the fourth grade of secondary schools. Lviv.

German, L., \& Petelenz, K. (1898). German exercises for the first grade of secondary schools. Lviv.

German, L., \& Petelenz, K. (1901). German exercises for the third grade of secondary schools. Lviv.

German, L., \& Petelenz, K. (1910). German exercises for the first grade of secondary schools. Lviv.

German, L., \& Petelenz, K. (1910). German exercises for the second grade of secondary schools. Lviv.

Introduction to the German language for the third grade of public schools. (1892). Lviv.

Ippoldt, J. (1904). Nauka języka niemieckiego w klasach wyższych naszych szkół srednich. Muzeum. Zeszyt, 4, 335-344.

Kokurenych, O. (1896). On teaching the German language in the third grade of public schools. Uchytel', 16-17, $245-251$.

Pachovsky, M. (1909). How much can you use the latest curriculum for the German language teaching language of instruction. Nasha shkola, 1-2, 51-61.

Salio, L. (1909). Teaching the German language in secondary schools and textbooks for it: the older Dr. Petelenz - Dr. Werner (1890-94) and the present Ippoldt et Stylo (1905-1909). Nasha shkola, 3-4, 98-111.

\section{ВИХРУЩ Н.}

Львівський національний університет імені Івана Франка, Львів, Україна

\section{ЗМІСТ І МЕТОДИКА ВИКЛАДАННЯ НІМЕЦЬКОЇ МОВИ В СЕРЕДНІХ ШКОЛАХ ЗАХІДНОЇ УКРАЇНИ (ДРУГА ПОЛОВИНА ХІХ - ПОЧАТОК ХХ СТОЛІТТЯ)}

Стаття присвячена аналізу змісту та методики викладання німецької мови в загальноосвітніх школах Західної України другої половини XIX - початку XX століття. Узагальнено позитивний історичний досвід Західної України у викладанні німецької мови, визначено особливості змісту та методики викладання німецької мови в загальноосвітніх школах у цей період та обгрунтовано важливість досліджень українських учених, освітян та методистів з метою вдосконалення змісту шкільної освіти в сучасних умовах. Для підвищення ефективності викладання німецької мови використовувались різні типи вправ: пояснювальне читання, читання фрагментів прозових та поетичних творів минулого з усним та письмовим переказом, усний та письмовий переклад, переписування 3 підручника, пояснювальні диктанти, вивчення віршів та фрагментів 3 прози та написання їх з пам'яті на уроках, граматичні та лексичні тести. Особливої уваги заслуговують думки про щоденне вивчення німецької мови, що граматичний матеріал не може лежати в основі вивчення німецької мови і повинен використовуватися для пояснення незрозумілих структур у текстах.

Ключові слова: німецька мова, зміст, навчальний план, методи, підручник 